\title{
Estrogen Enhances Matrix Synthesis in Nucleus Pulposus Cell through the Estrogen Receptor $\beta$-p38 MAPK Pathway
}

\author{
Pei Li ${ }^{a}$ Yuan Xu Yibo Gan ${ }^{\mathrm{a}}$ Liyuan Wang ${ }^{\mathrm{a}}$ Bin Ouyang ${ }^{\mathrm{a}}$ Chengmin Zhang \\ Lei Luo ${ }^{\mathrm{a}}$ Chen Zhao ${ }^{\mathrm{a}}$ Qiang Zhou ${ }^{\mathrm{a}}$ \\ aDepartment of Orthopedic Surgery, Southwest Hospital, Third Military Medical University, Chongqing, \\ ${ }^{b}$ Department of Orthopedic Surgery, Xinqiao Hospital, Third Military Medical University, Chongqing, \\ China
}

\section{Key Words}

Matrix $・ 17 \beta$-estradiol $•$ Estrogen receptor $\beta \cdot$ p38 MAPK $・$ Nucleus pulposus

\begin{abstract}
Background/Aims: Matrix homeostasis within the disc nucleus pulposus (NP) tissue is important for disc function. Increasing evidence indicates that sex hormone can influence the severity of disc degeneration. This study was aimed to study the role of $17 \beta$-estradiol $\left(E_{2}\right)$ in NP matrix synthesis and its underlying mechanism. Methods: Rat NP cells were cultured with (10 $5,10^{-7}$ and $10^{-9} \mathrm{M}$ ) or without (control) E2 for 48 hours. The estrogen receptor (ER)- $\beta$ antagonist PHTPP and ER $\beta$ agonist ERB 041 were used to investigate the role mediated by ER $\beta$. The p38 MAPK inhibitor SB203580 was used to investigate the role of p38 MAPK signaling pathway. Gene and protein expression of SOX9, aggrecan and collagen II, glycosaminoglycan (GAG) content, and immunostaining assay for aggrecan and collagen II were analyzed to evaluate matrix production in rat NP cells. Results: E2 enhanced NP matrix synthesis in a concentrationdependent manner regarding gene and proetin expression of SOX9, aggrecan and collagen II, protein deposition of aggrecan and collagen II, and GAG content. Moreover, activation of p38 MAPK signaling pathway was increased with elevating E2 concentration. Further analysis indicated that ERB 041 and PHTPP could respectively enhance and suppress effects of E2 on matrix synthesis in NP cells, as well as activation of p38 MAPK pathway. Additionally, inhibition of p38 MAPK signaling pathway significantly abolished the effects of E2 on matrix synthesis. Conclusion: E2 can enhance matrix synthesis of NP cells and the ER $\beta / p 38$ MAPK pathway is involved in this regulatory process.
\end{abstract}

\section{Introduction}

Intervertebral disc degeneration (IDD) is a common clinical disease which can cause low back pain and related neurologic symptoms [1,2]. Current therapies such as discectomy and spinal fusion cannot preserve the normal disc function. To date, the pathogenesis and repair strategy for disc degeneration are still research focuses [3-6]. 


\section{Cellular Physiology Cell Physiol Biochem 2016;39:2216-2226 \begin{tabular}{ll|l} 
and Biochemistry & $\begin{array}{l}\text { DOI: 10.1159/000447915 } \\
\text { Published online: November 07, } 2016\end{array}$ & $\begin{array}{l}\text { ( ) 2016 The Author(s). Published by S. Karger AG, Basel } \\
\text { www.karger.com/cpb }\end{array}$ \\
\hline
\end{tabular} Li et al.: Estrogen Enhances Matrix Synthesis in NP Cell}

During disc degeneration, loss of extracellular matrix (ECM) is a typical pathological event within the nucleus pulposus (NP) tissue. However, the molecular mechanism behind the loss of ECM within NP is underinvestigated. In recent years, accumulating evidence indicates that sex hormones can influence the severity of disc degeneration. For human disc, large sample-based study indicated that disc space narrowing is more prevent in postmenopausal women than premenopausal women and perimenopausal women [711]. Moreover, hormone replacement can increase disc height in postmenopausal women [12]. For animal disc, previous study demonstrated that female rat disc is susceptible to degenerate after undergoing ovariectomy [13]. Disc height narrowing is regarded as the most reliable radiographic sign of sever disc degeneration which is often characterized by loss of ECM within the central NP region $[7,8]$. Therefore, we speculate that estrogen may be able to enhance matrix synthesis within the disc NP region and that estrogen deficiency may contribute to advancing disc degeneration in postmenopausal women.

It is well known that the role of estrogen is often mediated by the estrogen receptors including estrogen receptor $\alpha(E R \alpha)$ and estrogen receptor $\beta$ (ER $\beta)$ [14-16]. Previous studies reported that the ER $\beta$ expression is existed in the human intervertebral disc [17] and that ER $\beta$ expression significantly decreases with aggravation of disc degeneration [18]. Previous studies manifested that ER $\beta$ is the main type of ER in cartilage $[19,20]$. Interaction of estrogen and ER $\beta$ in chondrocyte can induce biosynthesis of proteoglycan and collagen protein and thus maintain cartilage tissue homeostasis [21, 22]. Because the disc NP tissue is a hyaline cartilage which also mainly consists of proteoglycan and collagen II protein [1, 23 ], we speculate that the interaction of estrogen and ER $\beta$ plays an important role in matrix homeostasis within the disc NP tissue.

Mitogen-activated protein kinases (MAPKs) are the key pathway for transduction of extracellular stimuli into cellular biological responses[24]. Previously, several studies demonstrated that $\mathrm{p} 38 \mathrm{MAPK}$ signaling pathway plays an important role in matrix synthesis and cell viability within the disc NP region $[25,26]$. Moreover, several studies indicated that E2 could activate p38 MAPK pathway $[14,27]$ and that ER $\beta$ was involved in p38 MAPK activation $[28,29]$. Based on above statements, we deduce that the ER $\beta$ and p38 MAPK signaling pathway may be interconnected.

In the present study, we mainly aim to investigate the role of $17 \beta$-estradiol $\left(E_{2}\right)$ in the matrix synthesis and its underlying molecular mechanism. The ER $\beta$ antagonist PHTPP and ER $\beta$ agonist ERB 041 were used to investigate the role of ER $\beta$, and the p38 MAPK inhibitor SB203580 was used to investigate the role of p38 MAPK signaling pathway in this regulatory process. Matrix synthesis in NP cell was analyzed by gene and protein expression of SOX9, aggrecan and collagen II, immunostaining for matrix macromolecules (aggrecan and collagen II) and glycosaminoglycan (GAG) content.

\section{Materials and Methods}

\section{Ethical statement}

All experiments in this study were approved by the Ethics Committee at Southwest Hospital affiliated to the Third Military Medical University and were performed in accordance with the relevant guidelines [SYXK (YU) 2012-0012].

\section{NP cell isolation and culture}

Thirty-one healthy Sprague-Dawley rats (male, $250 \mathrm{~g}$ and 6-8 weeks old) were used in this part. Briefly, after sacrificing the rat with carbon dioxide, the thoracic and lumbar spinal columns were harvested and the separated thoracic and lumbar discs were all collected. And thereafter, the inner most NP tissue was separated from the annulus fibrosus under a dissecting microscope. Then, enzymatic digestion with $0.25 \%$ trypsin (Gibco, USA) for 5-10 minutes and 0.25\% Type I collagenase (Sigma, USA) for 10-15 minutes were sequentially followed. All collected NP cell pellets were re-suspended in monolayer culture with DMEM/ F12 (Hyclone, USA) containing 10\% (v/v) fetal bovine serum (FBS, Gibco, USA) and 1\% (v/v) penicillin- 


\section{Cellular Physiology Cell Physiol Biochem 2016;39:2216-2226 \begin{tabular}{ll|l} 
and Biochemistry Published online: November 07, 2016 & $\begin{array}{l}\text { ○ 2016 The Author(s). Published by S. Karger AG, Basel } \\
\text { www.karger.com/cpb }\end{array}$ \\
\hline
\end{tabular} \\ Li et al.: Estrogen Enhances Matrix Synthesis in NP Cell}

streptomycin (Gibco, USA). To avoid the interference caused by cell passage, the passage 2 (P2) NP cell was used in all experiments in the present study.

\section{Grouping information}

To observe effects of E2 (Abcam, USA) on matrix synthesis in NP cells, P2 NP cells were assigned into the following groups: (1) the control group that was free from intervention but incubated with the ethanol vehicle (<0.1\%); (2) the $10^{-9} \mathrm{M}$ E2 group; (3) the $10^{-7} \mathrm{M}$ E2 group; (4) the $10^{-5} \mathrm{M}$ E2 group. To investigate the role of ER $\beta$, the ER $\beta$ antagonist PHTPP ( $1 \mu \mathrm{M}, \mathrm{CSA}, \mathrm{USA})$ and ER $\beta$ agonist ERB 041 (10 $\mu \mathrm{M}, \mathrm{CSA}, \mathrm{USA})$ were added along the culture medium of the $10^{-5} \mathrm{M}$ E2 group. Similarly, the inhibitor SB203580 $(10 \mu \mathrm{M}$, Beyotime, China) was added into the culture medium of $10^{-5} \mathrm{M}$ E2 group to study the role of p38 MAPk signaling pathway. NP cells in all above groups were cultured under standard conditions $\left(37^{\circ} \mathrm{C}, 21 \% \mathrm{O}_{2}\right.$ and $\left.5 \% \mathrm{CO}_{2}\right)$.

\section{Real-time PCR analysis}

Gene expression (ER $\beta$, SOX9, aggrecan and collagen II) was detected by real-time PCR. After NP cells were incubated with different test compounds for 48 hours, total RNA was extracted using the Tripure Isolation Reagent (Roche) and synthesized into cDNA using the First Strand cDNA Synthesis Kit (Roche). Then, a reaction system including cDNA, SYBR Green Mix (TOYOBO) and primers (Table 1) was performed on a $\mathrm{C} 1000^{\mathrm{TM}}$ Thermal Cycler. $\beta$-actin was used as an internal reference and the relative gene expression normalized to the control group was expressed as $2^{-\Delta \Delta C t}$.

\section{Western blotting assay}

Protein expression of parameters indicating matrix synthesis (SOX9, aggrecan and collagen II) and activity of p38 MAPK pathway (p-p38 and p38) was analyzed by western blotting assay. Briefly, after NP cells were incubated with different test compounds for 48 hours, total protein was extracted with RIPA lysis solution (Beyotime, China), separated by SDS-PAGE and transferred to the PVDF membrane (Roche). Then, the PVDF membrane was incubated with primary antibodies ( $\beta$-actin: Proteitech, 60008-1-Ig, diluted; SOX9: Santa Cruz, sc-20095; collagen II: Abcam, ab34712; aggrecan: Santa Cruz, sc-16492) overnight at $4^{\circ} \mathrm{C}$ followed by incubation with the HRP-conjugated secondary antibody (ZSGB-BIO, China, diluted 1:2000) for 2 hours at room temperature. The protein brands on the membrane were visualized using the SuperSignal West Pico Trial Kit (Thermo) and analyzed using the Image J software (National Institutes of Health, USA).

\section{Immunocytochemistry}

Protein deposition of matrix macromolecules (aggrecan and collagen II) was analyzed by immunohistochemistry as previously described. Briefly, after incubation with different test compounds for 48 hours, NP cells were fixed with 4\% paraformaldehyde (Boster Biological Technology Co., Ltd, China) for 20 minutes. Then, NP cells were incubated with the primary antibodies (aggrecan: Norvus, NB12011570, diluted 1:200; collagen II: Abcam, ab34712, diluted 1:200) overnight at $4^{\circ} \mathrm{C}$ and the corresponding HRP-conjugated secondary antibody (ZSGB-BIO, China, diluted 1:200) for 2 hours at room temperature. Finally, the staining visualization with $\mathrm{DAB}$, counterstaining with hematoxylin solution and dehydration with graded ethanol were sequentially performed. Immuno-positive NP cells were observed under a light microscope (Olympus BX51, Japan) and analyzed using the Image-Pro Plus software (Version 5.1, Media Cybernetics, Inc.).

\section{GAG content measurement}

To quantify the GAG content synthesized by NP cells, DMMB assay was performed according to previous method [30]. Briefly, after NP cells were incubated with different test compounds for 48 hours, NP cells were collected and suspended in PBS containing $5 \mathrm{mg} / \mathrm{mL}$ papain (Sangon, Biotech Co., Ltd., China) for

Table 1. Primers of target genes

\begin{tabular}{lllc}
\hline Gene & Accession number & Forward (5'-3') & Reverse (5'-3') \\
\hline$\beta$-actin & NM_031144.3 & CCGCGAGTACAACCTTCTTG & TGACCCATACCCACCATCAC \\
SOX9 & NM_080403.1 & GAAAGACCACCCCGATTACA & TGAAGATGGCGTTAGGAGAGA \\
Aggrecan & XM_002723376.1 & ATGGCATTGAGGACAGCGAA & GCTCGGTCAAAGTCCAGTGT \\
Collagen II & NM_012929.1 & GCCAGGATGCCCGAAAATTAG & CCAGCCTTCTCGTCAAATCCT \\
\hline
\end{tabular}




\section{Cellular Physiology Cell Physiol Biochem 2016;39:2216-2226 \begin{tabular}{ll|l} 
and Biochemistry Published online: November 07, 2016 & $\begin{array}{l}\text { ○ 2016 The Author(s). Published by S. Karger AG, Basel } \\
\text { www.karger.com/cpb }\end{array}$ \\
\hline
\end{tabular} \\ Li et al.: Estrogen Enhances Matrix Synthesis in NP Cell}

6-8 hours at $60^{\circ} \mathrm{C}$. Then, the GAG content in digested sample was measured by absorbance value at $525 \mathrm{~nm}$ using the 1,9-dimethyl methylene blue (DMMB) assay, in which shark cartilage chondroitin sulfate (Sigma, USA) was used as a standard.

\section{Statistics}

Statistical analysis was performed using SPSS 13.0 software. All quantitative data were expressed as mean $\pm \mathrm{SD}$ of three independent experiments in this study. When homogeneity test for variance was completed, comparison among multi-groups was performed using one-way analysis of variance (ANOVA) and the post hoc test was determined by LSD test. A statistical difference was indicated when p-value $<0.05$.

\section{Results}

\section{I: Effects of E2 on matrix synthesis and p38 MAPK activity in NP cells}

E2 up-regulated expression of SOX9, aggrecan and collagen II in NP cells. Gene and protein expression of SOX9, aggrecan and collagen II were analyzed to evaluate matrix synthesis potency in NP cells. Results showed that E2 $\left(10^{-9}, 10^{-7}\right.$ and $\left.10^{-5}\right)$ could significantly up-regulated these molecules both at gene and protein levels, and that expression of these molecules was up-regulated with elevating the E2 concentration (Fig. 1).

E2 increased deposition of matrix protein and GAG content in NP cells. Protein deposition of aggrecan and collagen II and GAG content were analyzed to investigate matrix production in NP cells. Results showed that both aggrecan and collagen II deposition were increased by E2 incubation in a manner of concentration-dependent. Additionally, E2 also increased GAG content of NP cells, which became more obvious at high E2 concentration than at low E2 concentration (Fig. 2).

E2 significantly activated the p38 MAPK signaling pathway. Results showed that $\mathrm{p} 38$ MAPK signaling pathway was obviously activated by E2 incubation. Furthermore, activity of p38 MAPK pathway was dependent on E2 concentration (Fig. 3).

II: ER $\beta$ was involved in the effects of E2 on matrix synthesis and $p 38$ MAPK activity in NP cells

ER $\beta$ function was related with expression of SOX9, aggrecan and collagen II in E2-treated $N P$ cells. To investigate the role mediated by ER $\beta$, the specific ER $\beta$ antagonist PHTPP and ER $\beta$

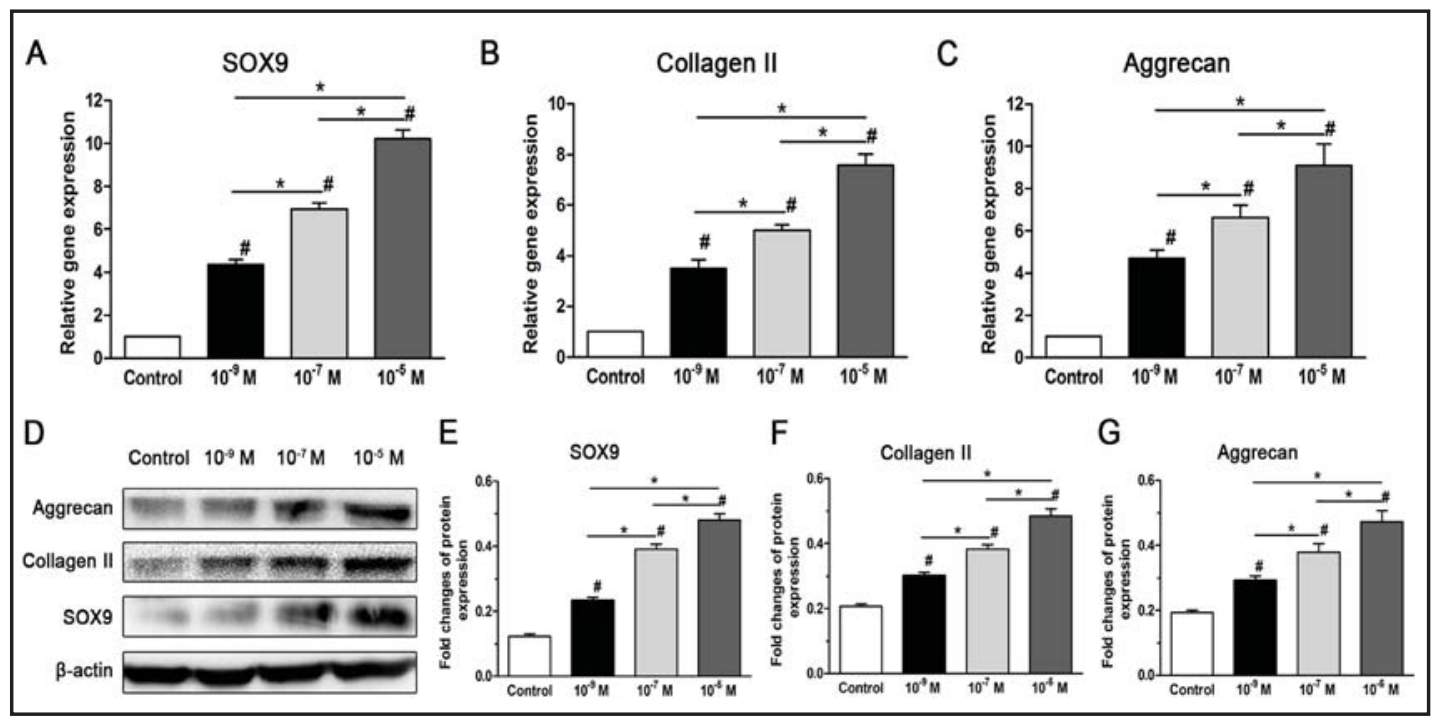

Fig. 1. 17 $\beta$-estradiol $\left(E_{2}\right)$ up-regulated gene $(A-C)$ and protein (D-G) expression of SOX9, aggrecan and collagen II of nucleus pulposus (NP) cells. Data are expressed as mean $\pm \mathrm{SD}, \mathrm{n}=3$. *: Indicates a significant difference between two groups. \#: Indicates a significant difference when compared with the control group. 


\section{Cellular Physiology Cell Physiol Biochem 2016;39:2216-2226 \begin{tabular}{ll|l} 
DOI: 10.1159/000447915 & O 2016 The Author(s). Published by S. Karger AG, Basel \\
and Biochemistry Published online: November 07, 2016 & www.karger.com/cpb
\end{tabular}}

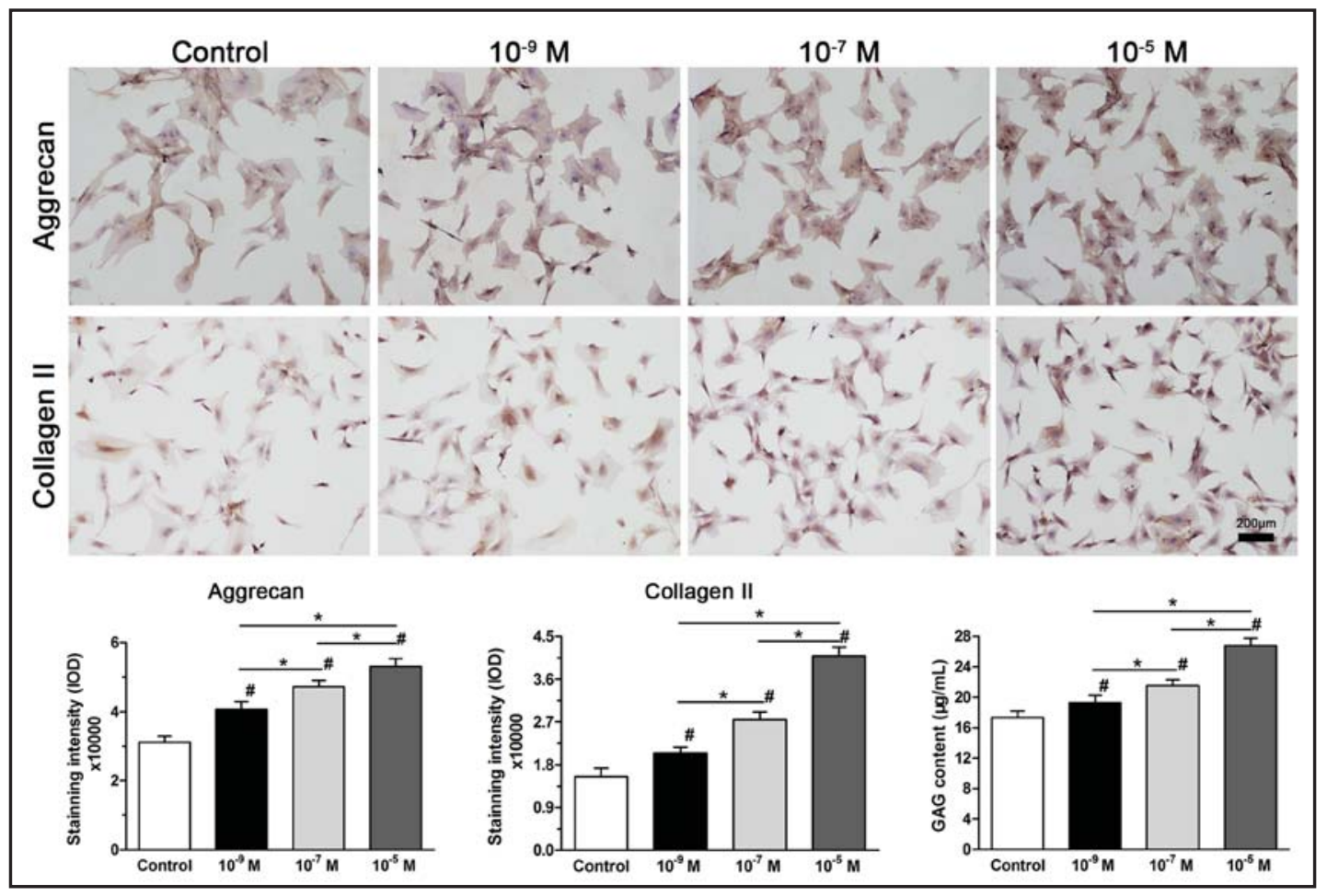

Fig. 2. $17 \beta$-estradiol $\left(\mathrm{E}_{2}\right)$ increased matrix protein (aggrecan and collagen II) deposition and glycosaminoglycan (GAG) content of nucleus pulposus (NP) cells. Data are expressed as mean $\pm \mathrm{SD}, \mathrm{n}=3$. *: Indicates a significant difference between two groups. \#: Indicates a significant difference when compared with the control group.

agonist ERB 041 were used to inhibit and activate $E R \beta$, respectively. Because the group with $10^{-5} \mathrm{M}$ E2 has a more obvious effect than other E2 concentrations, we just investigated the role of ER $\beta$ in the group with $10^{-5} \mathrm{M}$ E2. Results showed that the agonist ERB 041 and antagonist PHTPP could respectively upregulate and down-regulate expressions of SOX9, aggrecan and collagen II at gene and protein levels (Fig. 4).

ER $\beta$ function was related with deposition of matrix protein and GAG content in E2treated NP cells. Results showed that deposition of aggrecan and collagen II was decreased when the ER $\beta$ function was inhibited in the group with $10^{-5} \mathrm{M} \mathrm{E} 2$, whereas increased when the ER $\beta$ function was activated. Similarly, GAG content was increased and decreased by agonist ERB 041 and antagonist PHTPP, respectively (Fig. 5).

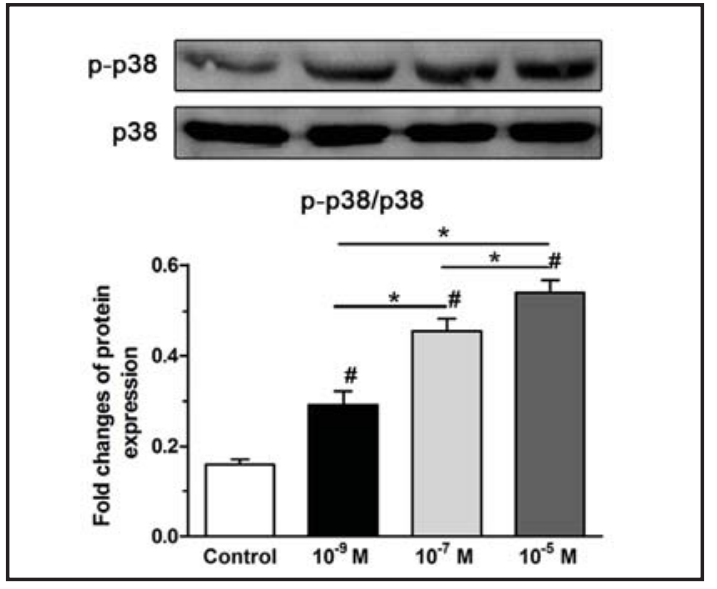

Fig. 3. 17ß-estradiol $\left(E_{2}\right)$ increased activity of p38 MAPK signaling pathway of nucleus pulposus (NP) cells. Data are expressed as mean $\pm S D, n=3$. *: Indicates a significant difference between two groups. \#: Indicates a significant difference when compared with the control group.

ER $\beta$ function was needed for activation of $p 38$ MAPK signaling pathway in E2-treated $N P$ cells. To analyze the interaction of ER $\beta$ and p38 MAPK signaling pathway, activation of p38 MAPK signaling pathway was investigated when the ER $\beta$ function was activated and inhibited, respectively. Results showed that activity of p38 MAPK signaling pathway was increased and decreased by the agonist ERB 041 and antagonist PHTPP (Fig. 6). 


\section{Cellular Physiology Cell Physiol Biochem 2016;39:2216-2226

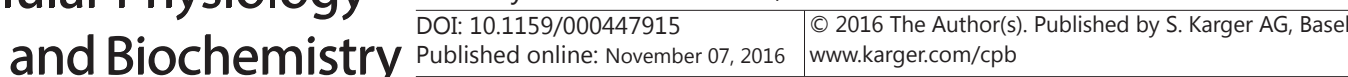

Li et al: Estrogen Enhances Matrix Synthesis in NP Cell

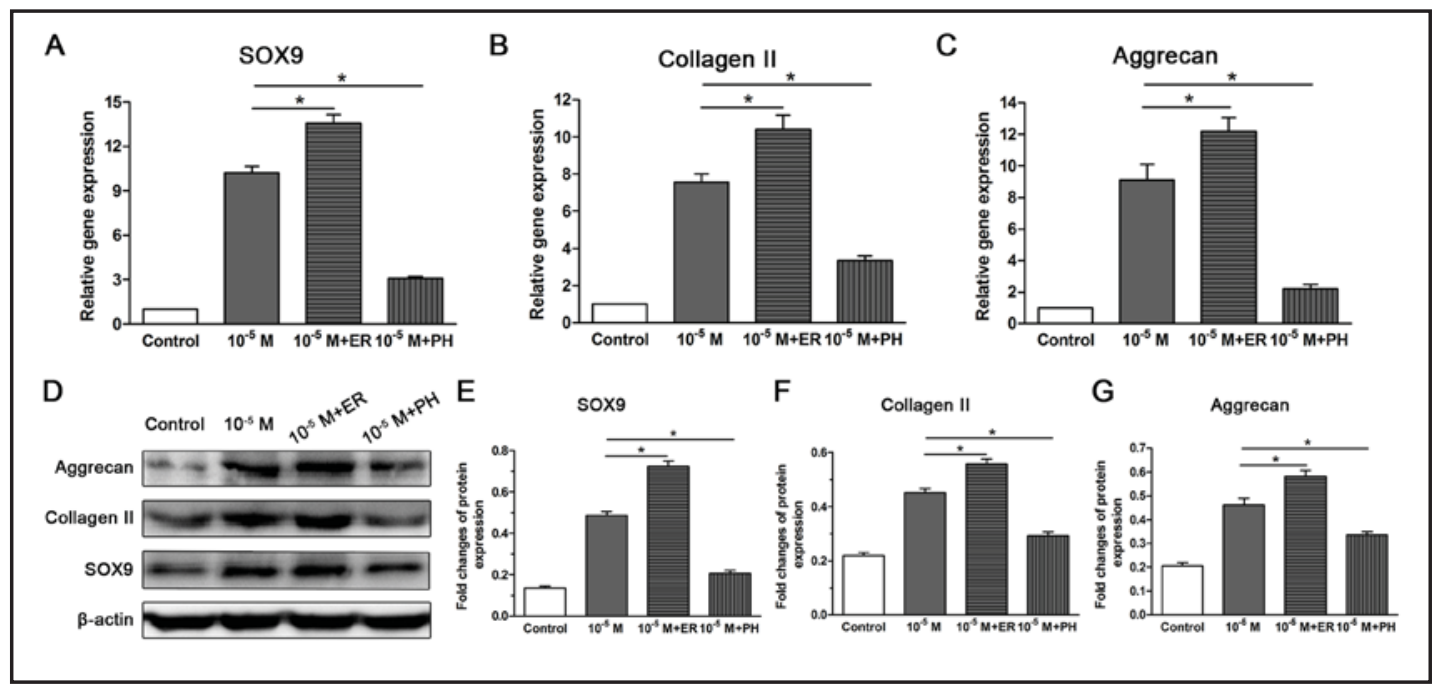

Fig. 4. Estrogen receptor- $\beta$ (ER $\beta$ ) was related with expression of SOX9, aggrecan and collagen II in E2-treated nucleus pulposus (NP) cells. ER $\beta$ antagonist PHTPP and ER $\beta$ agonist ERB 041 significantly down-regulated and up-regulated expression of SOX9, aggrecan and collagen II in $17 \beta$-estradiol $\left(\mathrm{E}_{2}\right)$-treated nucleus pulposus (NP) cells. Data are expressed as mean \pm SD, $n=3$. *: Indicates a significant difference between two groups.

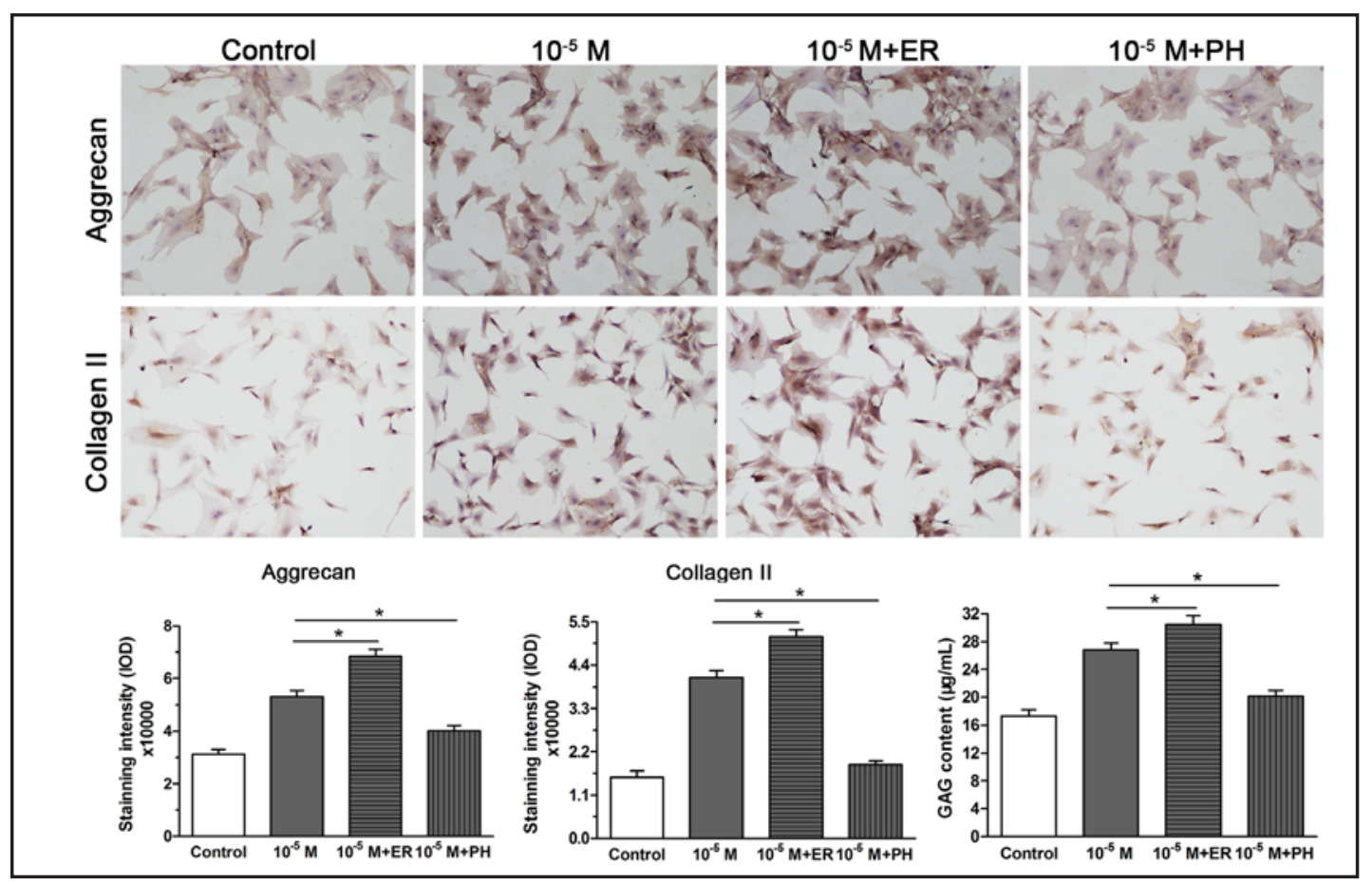

Fig. 5. Estrogen receptor- $\beta$ (ER $\beta$ ) was related with matrix protein (aggrecan and collagen II) deposition and glycosaminoglycan (GAG) content of E2-treated nucleus pulposus (NP) cells. Data are expressed as mean \pm $\mathrm{SD}, \mathrm{n}=3$. *: Indicates a significant difference between two groups.

III: Inhibition of p38 MAPK signaling pathway attenuated the effects of E2 on matrix synthesis in NP cells

To evaluate the role of p38 MAPK signaling pathway in the effects of E2 on matrix synthesis of NP cells, activation of p38 MAPK pathway in the group with $10^{-5} \mathrm{M}$ E2 was inhibited by its specific inhibitor SB203580 (Fig. 7A). Results showed that inhibition of p38 MAPK pathway significantly attenuated matrix synthesis potential induced E2, which was 


\section{Cellular Physiology Cell Physiol Biochem 2016;39:2216-2226 \begin{tabular}{ll|l} 
DOI: 10.1159/000447915 & O 2016 The Author(s). Published by S. Karger AG, Basel \\
and Biochemistry Published online: November 07, 2016 & www.karger.com/cpb
\end{tabular}}

Fig. 6. Activation and inhibition of estrogen receptor- $\beta$ $(E R \beta)$ significantly increased and decreased activity of p38 MAPK pathway in E2-treated nucleus pulposus (NP) cells. Data are expressed as mean $\pm S D, n=3$. : Indicates a significant difference between two groups.
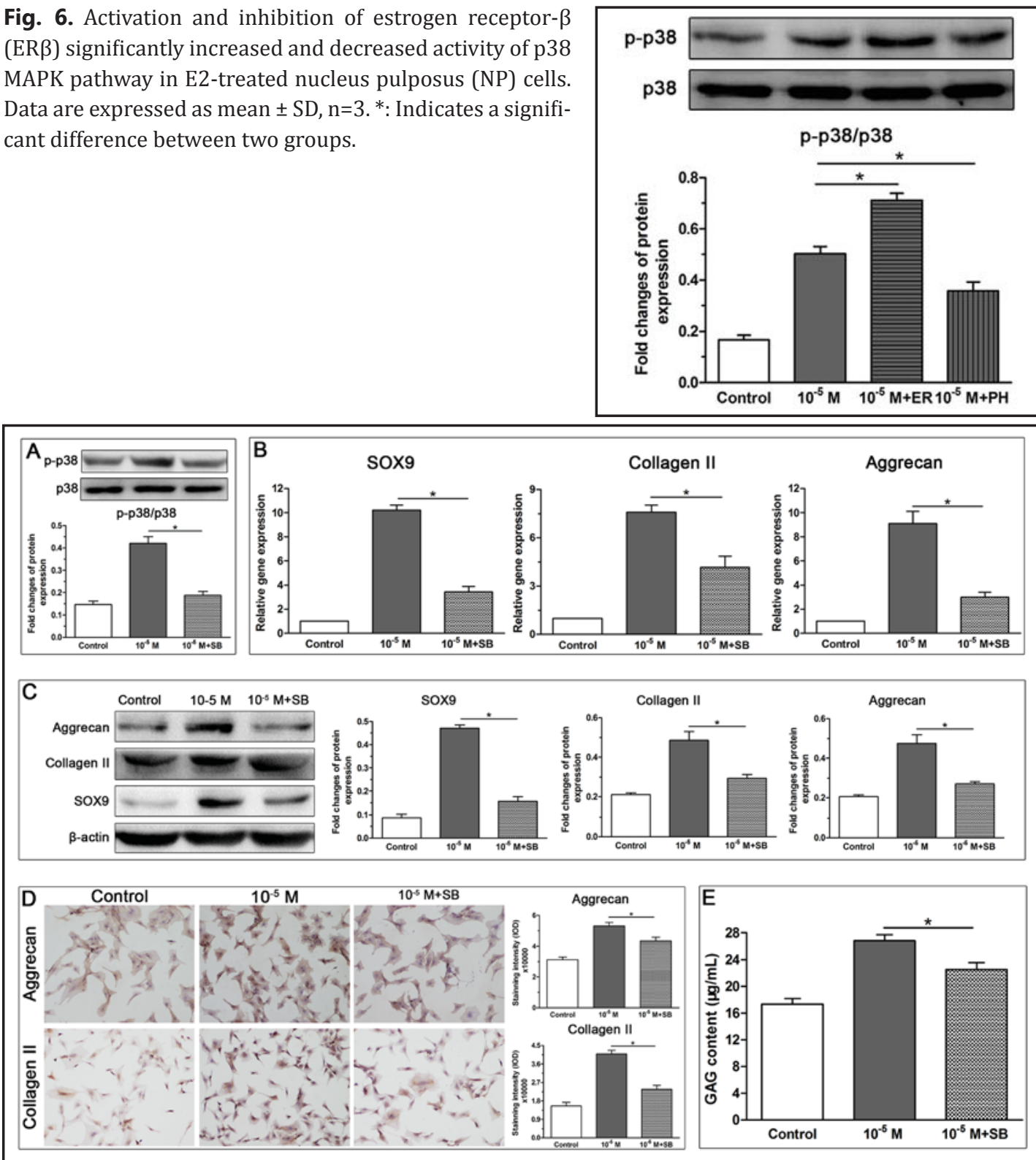

Fig. 7. Inhibition of p38 MAPK pathway significantly attenuated effects of $17 \beta$-estradiol $\left(E_{2}\right)$ on matrix synthesis in NP cells. Data are expressed as mean \pm SD, $n=3$. *: Indicates a significant difference between two groups.

indicated by the down-regulated gene and protein expression of SOX9, aggrecan and collagen II, decreased deposition of aggrecan and collagen II and declined GAG content compared with those in the group with $10^{-5} \mathrm{M}$ E2 (Fig. 7B-E).

\section{Discussion}

Matrix homeostasis within the NP region is crucial for normal disc function and the resulting spine mechanical stability [31]. As an estrogen sensitive tissue, previous studies indicated that estrogen can increase disc height of post-menopausal women, promote proliferation of disc cells and inhibit inflammatory cytokine-induced apoptosis of disc cells $[8,12,17,32-34]$. Further more, estrogen can attenuate inflammatory cytokine-induced cellular senescence of disc NP cells in our previous study (unpublished data, submitted to 


\section{Cellular Physiology Cell Physiol Biochem 2016;39:2216-2226 \\ \begin{tabular}{ll|l} 
and Biochemistry & $\begin{array}{l}\text { DOI: 10.1159/000447915 } \\
\text { Published online: November 07, } 2016\end{array}$ & $\begin{array}{l}\text { ( ) 2016 The Author(s). Published by S. Karger AG, Basel } \\
\text { www.karger.com/cpb }\end{array}$ \\
\hline
\end{tabular} \\ Li et al.: Estrogen Enhances Matrix Synthesis in NP Cell}

International Journal of Biological Sciences). However, the effects of E2 on matrix synthesis of NP cells and possible mechanism behind this process were unclear. The main objective of this study was to investigate effects of E2 on matrix synthesis potential of NP cells and the underlying mechanism. Our results demonstrated that E2 could enhance matrix synthesis of NP cells in a manner of concentration-dependent, and that the ER $\beta$-p38 MAPK pathway may be involved in this regulatory process. This study indirectly provides explanations to the efficiency of estrogen-replacement in retarding the disc height in post-menopausal women and brings a promising strategy to regenerate degenerative disc in the future.

Apart from the peripheral annulus fibrosus (AF) and the upper and lower cartilage endplates (EPs), the central NP is important for normal disc function $[1,35]$. The large amount of proteoglycan within disc NP tissue contributes to a high fixed negative charge to the NP matrix due to its negatively charged glycosaminoglycan chains[36]. Precisely because of the high NP hydration resulted from the negatively charged glycosaminoglycan, the disc allows for spine motion and maintains a uniform stress distribution of the disc endplates. However, the disc NP region undergoes progressive biochemical changes during degeneration and aging, such as decrease in proteoglycan content, decline of tissue hydration and transition of collagen type I to collagen type II [37], which can return significantly broken disc mechanical function. Therefore, strategies that can restore matrix homeostasis within the disc NP region may be feasible to partly regenerate the degenerated disc.

Estrogen has some important effects on articular cartilage. A clinical study by Lou et al. reported that estrogen deficiency was associated with progressive degeneration of knee joint cartilage in post-menopausal women [38]. Besides, several cell culture studies also demonstrated that estrogen reduced expression of matrix degrade enzymes (MMP-1, - 3 and $-13)$ and increased collagen and proteoglycan production in cartilage cells $[39,40]$. These studies all indicate that estrogen may have favorable effects on cartilage helpful to matrix homeostasis in articular cartilage. Matrix composition within the disc NP region is similar to that within the articular cartilage. Though clinical study reported that estrogen deficiency was related with decrease in disc height in post-menopausal women [8, 12], and basic researches demonstrated that estrogen could promote proliferation and inhibit apoptosis of NP cells [17, 32], effects of estrogen on matrix synthesis of disc NP cells are not clear.

SOX9 is a high-mobility group (HMG) domain transcription factor that can positively regulate expression of chondrocyte-specific genes including aggrecan and collagen II [41]. In the present study, we found that gene and protein expression of SOX9, aggrecan and collagen II increased with elevating E2 concentration. Further more, matrix protein (aggrecan and collagen II) deposition and GAG content showed a similar trend in NP cells incubated with E2. These positive effects of E2 on NP cells were in line with that on articular chondrocytes, and indicate that E2 can promote matrix synthesis potential of disc NP cells.

ER $\beta$ is also expressed in the disc tissue and down-regulated with advancing disc degeneration $[17,18]$. To investigate the role of ER $\beta$ in the effects of E2, the specific ER $\beta$ antagonist PHTPP and ER $\beta$ agonist ERB 041 were used to inhibit and activate ER $\beta$ function. Results showed that ER $\beta$ was involved in the effects of E2 on matrix synthesis of NP cells, which was indicated by the up-regulated gene and protein expression of matrix molecules (aggrecan and collagen II), increased matrix protein deposition and GAG content when the ER $\beta$ was activated, and the opposite outcomes when the ER $\beta$ was inhibited. The different effects of E2 on matrix synthesis resulted from the altered ER $\beta$ activity indicated that classical ligand-receptor interaction between E2 and ER $\beta$ contributes to the promoted matrix synthesis potential of NP cells.

There is evidence that p38 MAPK signaling pathway is involved in matrix synthesis and viability of disc cells $[25,26]$. Previous studies demonstrated that E2 can activate p38 MAPK signaling pathway $[14,27]$. To investigate whether p38 MAPK signaling pathway is participated in the effects caused by E2- ER $\beta$ interaction on matrix synthesis of NP cells, the activity of $\mathrm{p} 38$ MAPK pathway and NP matrix synthesis were investigated when ER $\beta$ function was activated and inhibited, respectively. Results showed that activity of p38 MAPK pathway in NP cells increased with elevating E2 concentration. This is in line with previous study on 


\section{Cellular Physiology Cell Physiol Biochem 2016;39:2216-2226 \\ \begin{tabular}{ll|l} 
and Biochemistry & $\begin{array}{l}\text { DOI: 10.1159/000447915 } \\
\text { Published online: November 07, } 2016\end{array}$ & $\begin{array}{l}\text { ( ) 2016 The Author(s). Published by S. Karger AG, Basel } \\
\text { www.karger.com/cpb }\end{array}$ \\
\hline
\end{tabular} \\ Li et al.: Estrogen Enhances Matrix Synthesis in NP Cell}

other cell types [14, 27]. Additionally, activity of p38 MAPK signaling pathway was increased and decreased when the ER $\beta$ function was activated and inhibited, respectively. Meanwhile, matrix synthesis potential of NP cells displayed a similarly consistent trend after the ER $\beta$ function was altered. Finally, inhibition the p38 MAPK pathway along also attenuated the favorable effect of E2 on matrix synthesis in NP cells. These findings indicate that ER $\beta$ is the upstream molecule of p38 MAPK pathway in the regulatory role of E2 in promoting matrix synthesis of NP cells. The downstream of estrogen mediated signal is very complicated. Previous study reported that $\mathrm{E} 2$ can rapidly activate protein kinase $\mathrm{C}$ (PKC) which can initiate changes in gene expression through the MAPK pathway [42-44]. To accurately understand the underlying mechanism behind the favorable effects of E2 on matrix synthesis in NP cells, more researches are needed in the future.

Because the main objective of the present study was to investigate the effects of estrogen on matrix synthesis of NP cells, experimental female rats were excluded to avoid certain interference caused by menses cycle. Besides, though estrogen can perform functions through ER $\beta$ which expressed in disc NP tissue in both men and women, care should be taken when the present data were applied to potential clinical interest for both male and female patients since the gender differences in the expression of ER $\beta$ in NP cells [18]. The protective effects of estrogen on matrix synthesis of NP cells may indirectly provide explanations to the efficiency of estrogen-replacement in retarding the disc height in post-menopausal women. However, more researches are needed to verify whether these results can apply to male patients. Additionally, though interaction between E2 and ER $\beta$ was only investigated at the high E2 concentration $\left(10^{-5} \mathrm{M}\right)$, we speculate that ER $\beta$ can also play a role in the effects of other estrogen concentrations $\left(10^{-9} \mathrm{M}\right.$ and $\left.10^{-7} \mathrm{M}\right)$ according to our results.

This study also has several limitations. First, ER $\alpha$ also expressed in the disc NP tissue [18]. However, we mainly focused on the interaction between $E_{2}$ and ER $\beta$ in the present study since ER $\beta$ is the main type of ER in cartilaginous tissue [19, 20]. Second, NP cells were platecultured under the normal oxygen condition in this study. Physiologically, NP cells often grow in a 3D environment and face a hypoxic condition $[36,45]$. Third, the rat disc NP cells were isolated from normal non-degenerated rat disc. Due to the difference in cellular composition and disc degeneration status between the normal rat disc and degenerated human disc [46], it is unknown that whether matrix synthesis potential of NP cells from the degenerative human disc also responses well to E2. In fact, we have developed an alginate system consisted of glucan, gelatin and polyethylene glycol. This alginate system showed preferable cellular biocompatibility with NP cells and maintained the normal NP cell phenotype in vitro according to our existing experience. To study effects of E2 on matrix synthesis potential of human degenerative disc NP cells, If possible, we will culture the degenerative human disc NP cells in this 3D alginate system under hypoxic condition in the future.

To conclude, this study provides novel information about the effects of E2 on matrix synthesis of NP cells and the underlying mechanism. Our results indicated that E2 promote matrix synthesis of NP cells through the ER $\beta$-p38 MAPK pathway. This study sheds a light on the favorable role of estrogen in promoting matrix synthesis of NP cells and provides some theoretical foundations to the restored disc height by estrogen-replacement in postmenopausal women.

\section{Acknowledgments}

This study was supported by the National Natural Science Foundation of China (NSFC 81272029 and NSFC 81027005), Science and Technology Achievement Transformation Fund, the Third Military Medical University (2011XZH006). We also thank Dr. Fuyun Ji for technical assistance.

\section{Disclosure Statement}

The authors do not have any conflicts of interest related to this work. 


\section{Cellular Physiology Cell Physiol Biochem 2016;39:2216-2226 \begin{tabular}{ll|l} 
and Biochemistry $10.1159 / 000447915$ & $\begin{array}{l}\text { C 2016 The Author(s). Published by S. Karger AG, Basel } \\
\text { www.karger.com/cpb }\end{array}$ \\
\hline
\end{tabular}}

Li et al.: Estrogen Enhances Matrix Synthesis in NP Cell

\section{References}

1 Vedicherla S, Buckley CT: Cell-based therapies for intervertebral disc and cartilage regeneration - current concepts, parallels and perspectives. J Orthop Res 2016;10.1002/jor.23268

2 Priyadarshani P, Li Y, Yao L: Advances in biological therapy for nucleus pulposus regeneration. Osteoarthritis Cartilage 2016;24:206-212.

3 Liu Z, Zhou K, Fu W, Zhang H: Insulin-Like Growth Factor 1 Activates PI3k/Akt Signaling to Antagonize Lumbar Disc Degeneration. Cell Physiol Biochem 2015;37:225-232.

4 Yan N, Yu S, Zhang H, Hou T: Lumbar Disc Degeneration is Facilitated by MiR-100-Mediated FGFR3 Suppression. Cell Physiol Biochem 2015;36:2229-2236.

5 Feng C, Liu H, Yang Y, Huang B, Zhou Y: Growth and differentiation factor-5 contributes to the structural and functional maintenance of the intervertebral disc. Cell Physiol Biochem 2015;35:1-16.

6 Chen JW, Ni BB, Li B, Yang YH, Jiang SD, Jiang LS: The responses of autophagy and apoptosis to oxidative stress in nucleus pulposus cells: implications for disc degeneration. Cell Physiol Biochem 2014;34:11751189.

7 Wang YX, Griffith JF: Effect of menopause on lumbar disk degeneration: potential etiology. Radiology 2010;257:318-320.

8 Gambacciani M, Pepe A, Cappagli B, Palmieri E, Genazzani AR: The relative contributions of menopause and aging to postmenopausal reduction in intervertebral disk height. Climacteric 2007;10:298-305.

9 Lou C, Chen HL, Feng XZ, Xiang GH, Zhu SP, Tian NF, Jin YL, Fang MQ Wang C, Xu HZ: Menopause is associated with lumbar disc degeneration: a review of 4230 intervertebral discs. Climacteric 2014;17:700704.

10 Calleja-Agius J, Muscat-Baron Y, Brincat MP: Estrogens and the intervertebral disc. Menopause Int 2009;15:127-130.

11 Wang YX, Wang JQ Kaplar Z: Increased low back pain prevalence in females than in males after menopause age: evidences based on synthetic literature review. Quant Imaging Med Surg 2016;6:199-206.

12 Baron YM, Brincat MP, Galea R, Calleja N: Intervertebral disc height in treated and untreated overweight post-menopausal women. Hum Reprod 2005;20:3566-3570.

13 Wang T, Zhang L, Huang C, Cheng AG, Dang GT: Relationship between osteopenia and lumbar intervertebral disc degeneration in ovariectomized rats. Calcif Tissue Int 2004;75:205-213.

14 McMillan J, Fatehi-Sedeh S, Sylvia VL, Bingham V, Zhong M, Boyan BD, Schwartz Z: Sex-specific regulation of growth plate chondrocytes by estrogen is via multiple MAP kinase signaling pathways. Biochim Biophys Acta 2006;1763:381-392.

15 Martin-Millan M, Castaneda S: Estrogens, osteoarthritis and inflammation. Joint Bone Spine 2013;80:368373.

16 Hammes SR, Levin ER: Extranuclear steroid receptors: nature and actions. Endocr Rev 2007;28:726-741.

17 Gruber HE, Yamaguchi D, Ingram J, Leslie K, Huang W, Miller TA, Hanley EN, Jr.: Expression and localization of estrogen receptor-beta in annulus cells of the human intervertebral disc and the mitogenic effect of 17-beta-estradiol in vitro. BMC Musculoskelet Disord 2002;3:4.

18 Song XX, Yu YJ, Li XF, Liu ZD, Yu BW, Guo Z: Estrogen receptor expression in lumbar intervertebral disc of the elderly: gender- and degeneration degree-related variations. Joint Bone Spine 2014;81:250-253.

19 Pelletier G: Localization of androgen and estrogen receptors in rat and primate tissues. Histol Histopathol 2000;15:1261-1270.

20 Bay-Jensen AC, Slagboom E, Chen-An P, Alexandersen P, Qvist P, Christiansen C, Meulenbelt I, Karsdal MA: Role of hormones in cartilage and joint metabolism: understanding an unhealthy metabolic phenotype in osteoarthritis. Menopause 2013;20:578-586.

21 Ham KD, Oegema TR, Loeser RF, Carlson CS: Effects of long-term estrogen replacement therapy on articular cartilage IGFBP-2, IGFBP-3, collagen and proteoglycan levels in ovariectomized cynomolgus monkeys. Osteoarthritis Cartilage 2004;12:160-168.

22 Richmond RS, Carlson CS, Register TC, Shanker G, Loeser RF: Functional estrogen receptors in adult articular cartilage: estrogen replacement therapy increases chondrocyte synthesis of proteoglycans and insulin-like growth factor binding protein 2. Arthritis Rheum 2000;43:2081-2090.

23 Henriksson HB, Brisby H: Development and regeneration potential of the mammalian intervertebral disc. Cells Tissues Organs 2013;197:1-13.

24 Yang SH, Sharrocks AD, Whitmarsh AJ: Transcriptional regulation by the MAP kinase signaling cascades. Gene 2003;320:3-21. 


\section{Cellular Physiology Cell Physiol Biochem 2016;39:2216-2226 \begin{tabular}{ll|l} 
and Biochemistry $10.1159 / 000447915$ & $\begin{array}{l}\text { C 2016 The Author(s). Published by S. Karger AG, Basel } \\
\text { www.karger.com/cpb }\end{array}$ \\
\hline
\end{tabular} \\ Li et al.: Estrogen Enhances Matrix Synthesis in NP Cell}

25 Li P, Gan Y, Xu Y, Li S, Song L, Li S, Li H, Zhou Q: Osmolarity affects matrix synthesis in the nucleus pulposus associated with the involvement of MAPK pathways: A study of ex vivo disc organ culture system. J Orthop Res 2016;34:1092-1100.

26 Ariga K, Yonenobu K, Nakase T, Hosono N, Okuda S, Meng W, Tamura Y, Yoshikawa H: Mechanical stressinduced apoptosis of endplate chondrocytes in organ-cultured mouse intervertebral discs: an ex vivo study. Spine (Phila Pa 1976) 2003;28:1528-1533.

27 Singh M, Setalo G, Jr., Guan X, Warren M, Toran-Allerand CD: Estrogen-induced activation of mitogenactivated protein kinase in cerebral cortical explants: convergence of estrogen and neurotrophin signaling pathways. J Neurosci 1999;19:1179-1188.

28 Geraldes P, Sirois MG, Tanguay JF: Specific contribution of estrogen receptors on mitogen-activated protein kinase pathways and vascular cell activation. Circ Res 2003;93:399-405.

29 Chen J, Hou R, Zhang X, Ye Y, Wang Y, Tian J: Calycosin suppresses breast cancer cell growth via ERbetadependent regulation of IGF-1R, p38 MAPK and PI3K/Akt pathways. PLoS One 2014;9:e91245.

30 Farndale RW, Sayers CA, Barrett AJ: A direct spectrophotometric microassay for sulfated glycosaminoglycans in cartilage cultures. Connect Tissue Res 1982;9:247-248.

31 Hu B, Shi C, Tian Y, Zhang Y, Xu C, Chen H, Cao P, Yuan W: TGF-beta Induces Up-Regulation of Chondroitin Sulfate Synthase 1 (CHSY1) in Nucleus Pulposus Cells Through MAPK Signaling. Cell Physiol Biochem 2015;37:793-804.

32 Wang H, Ding W, Yang D, Gu T, Yang S, Bai Z: Different concentrations of 17beta-estradiol modulates apoptosis induced by interleukin-1beta in rat annulus fibrosus cells. Mol Med Rep 2014;10:2745-2751.

33 Yang SD, Ma L, Gu TX, Ding WY, Zhang F, Shen Y, Zhang YZ, Yang DL, Zhang D, Sun YP, Song YL: 17betaEstradiol protects against apoptosis induced by levofloxacin in rat nucleus pulposus cells by upregulating integrin alpha2beta1. Apoptosis 2014;19:789-800.

34 Yang SD, Yang DL, Sun YP, Wang BL, Ma L, Feng SQ, Ding WY: 17beta-estradiol protects against apoptosis induced by interleukin-1 beta in rat nucleus pulposus cells by down-regulating MMP-3 and MMP-13. Apoptosis 2015;20:348-357.

35 Li P, Gan Y, Wang H, Xu Y, Song L, Zhang C, Li S, Zhou Q: Biological Responses of the Immature Annulus Fibrosus to Dynamic Compression in a Disc Perfusion Culture. Cells Tissues Organs 2016;10.1159/000446363

36 Urban JP: The role of the physicochemical environment in determining disc cell behaviour. Biochem Soc Trans 2002;30:858-864.

37 Sakai D, Grad S: Advancing the cellular and molecular therapy for intervertebral disc disease. Adv Drug Deliv Rev 2015;84:159-171.

38 Lou C, Xiang G, Weng Q, Chen Z, Chen D, Wang Q, Zhang D, Zhou B, He D, Chen H: Menopause is associated with articular cartilage degeneration: a clinical study of knee joint in 860 women. Menopause 2016;10.1097/gme.0000000000000697

39 Cheng P, Ma X, Xue Y, Li S, Zhang Z: Effects of estradiol on proliferation and metabolism of rabbit mandibular condylar cartilage cells in vitro. Chin Med J (Engl) 2003;116:1413-1417.

40 Claassen H, Steffen R, Hassenpflug J, Varoga D, Wruck CJ, Brandenburg LO, Pufe T: 17beta-estradiol reduces expression of MMP-1, -3 , and -13 in human primary articular chondrocytes from female patients cultured in a three dimensional alginate system. Cell Tissue Res 2010;342:283-293.

41 Bi W, Deng JM, Zhang Z, Behringer RR, de Crombrugghe B: Sox9 is required for cartilage formation. Nat Genet 1999;22:85-89.

42 Doolan CM, Condliffe SB, Harvey BJ: Rapid non-genomic activation of cytosolic cyclic AMP-dependent protein kinase activity and [Ca(2+)](i) by 17 beta-oestradiol in female rat distal colon. Br J Pharmacol 2000;129:1375-1386.

43 Morrison DK: MAP kinase pathways. Cold Spring Harb Perspect Biol 2012;4:pii:a011254. doi: 10.1101/ cshperspect.a011254.

44 Morelli S, Buitrago C, Boland R, de Boland AR: The stimulation of MAP kinase by 1,25(OH)(2)-vitamin D(3) in skeletal muscle cells is mediated by protein kinase $C$ and calcium. Mol Cell Endocrinol 2001;173:41-52.

45 Ejeskar A, Holm S: Oxygen tension measurements in the intervertebral disc. A methodological and experimental study. Ups J Med Sci 1979;84:83-93.

46 Alini M, Eisenstein SM, Ito K, Little C, Kettler AA, Masuda K, Melrose J, Ralphs J, Stokes I, Wilke HJ: Are animal models useful for studying human disc disorders/degeneration? Eur Spine J 2008;17:2-19. 